УДК 913:001.4

ББК 26.8в3

DOI 10.25281/2072-3156-2018-15-6-729-739

\title{
Е.С. ТРИФИЛОВА
}

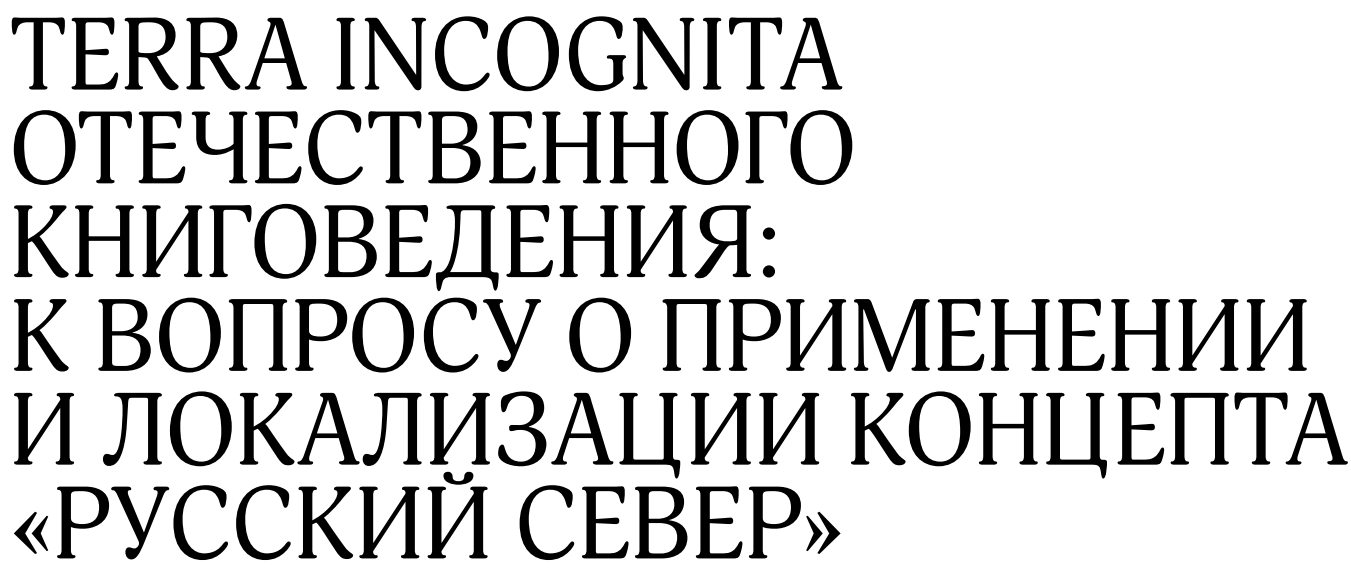

\section{Елена Сергеевна Трифилова,}

Российская государственная библиотека, отдел рукописей,

главный архивист

Воздвиженка ул., д. 3/5, Москва, 119019, Россия

E-mail: estrifilova@gmail.com

Реферат. Понятие «Русский Север» активно используется в СМИ и научной литературе. При этом мало кто задумывается над его значением. В области книговедения неопределенность представления о территории Русского Севера затрудняет отбор материала для исследования книжной культуры данного региона. Анализ практики использования конщепта показывает, что проблема возникла еще в ХІХ в., когда исследователи по-разному определяли территорию Русского Севера. В большинстве случаев они руководствовались выводами исторической науки, относящей к этому региону все земли, когда-либо и как-либо связанные с Новгородской республикой. Стереотип, сформировавшийся почти 200 лет назад, бытует и по сей день. Однако данные, полученные в результате археологических и исторических исследований, проведенных в течение последних 50 лет, ставят под сомнение правомочность существования новгородской парадигмы.
В этнографии, данные которой стали активно использоваться в книговедческих исследованиях во второй половине ХХ в., также нет единого мнения по поводу территориального состава Русского Севера. Попытки совместить его границы с границами ареалов распространения севернорусских диалектов и комплекса традищионной севернорусской бытовой культуры показали неэффективность метода в современных условиях. Появившиеся на рубеже ХХ-ХХІ вв. культурологические теории, с одной стороны, предложили новые аспекты исследования Русского Севера, а с другой - вывели его в область абстракции, фактически лишив географических привязок. Поскольку на сегодняшний день тема о локализации Русского Севера в книговедении остается открытой, цель настоящего исследования - попытаться систематизировать и проанализировать накопленную информацию. В результате поставлены вопросы о необходимости дальнейшего сохранения стереотипа, о правомочности причисления к Русскому Северу территорий, не имеющих к нему отношения с точки зрения географии, или имеющих условное отношение с точки зрения истории, о корректности применения топонимической формы концепта к Северу Европейской части России без учета Севера Сибири. Наконеи, некоторая корректировка была предпринята в отношении 
авторства термина «Русский Север», которое традиционно приписывается архангельскому гражданскому губернатору А.П. Энгельгардту.

Ключевые слова: Русский Север, книговедение, археография, этнография, Север Европейской части России, А.П. Энгельгардт.

Для цитирования: Трифилова E.C. Terra incognita отечественного книговедения: к вопросу о применении и локализации концепта «Русский Север» // Обсерватория культуры. 2018. Т. 15, № 6. C. 729-739. DOI: 10.25281/2072-3156-2018-15-6-729-739.

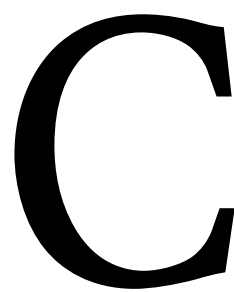

ложно не согласиться с утверждением, что «Русский Север - один из самых изученных и едва ли не самый неизведанный из регионов России» $[1$, с. 5-6], особенно если учесть активное применение концепта как в СМИ, так и в науке. Но «используя понятие "Русский Север”, исследователи редко задумываются над его возникновением и значением...» [2, с. 6]. Причину этого явления культурологи видят в трансформации, которую претерпело географическое понятие «Русский Север», превратившись в «макрорегиональный топоним... за которым... стоит мощный культурно-ландшафтный регион Русский Север» [3, c. 217]. В таком случае возникает вопрос о целесообразности определения границ «Русского Севера». Безусловно, не будучи локализованным, это понятие открывает простор для теоретизирования. Но как быть исследователям, для которых Русский Север является конкретным, а не абстрактным объектом изучения? Процесс отбора материала неизбежно приведет к вопросу о границах зоны исследования.

Для книговедения эта проблема приобретает особую актуальность в связи с развивающейся тенденцией к изучению региональной книжной культуры, а Русский Север вполне может выступать в качестве объекта исследований на макрорегиональном уровне. Книжные и документные памятники какой территории следует или возможно определить как севернорусские? Что такое «Русский Север» и насколько правомочно в книговедении употребление топонимической формы этого понятия? Рассмотрение этих вопросов и является целью статьи. В рамках нашего небольшого обзора мы не будем касаться понятия «Поморье», которое часто употребляется наряду с концептом «Русский Север» или отождествляется с ним. Эта тема не менее актуальна и требует отдельного рассмотрения.

Большинство исследователей стараются обходить стороной вопросы локализации, акцентируя внимание на палеографических и текстологических особенностях памятника, несмотря на то, что еще в 1972 г., основоположник библиогеографии Н.Н. Розов говорил о необходимости определения сначала места, а затем времени происхождения памятника. В рамках книговедения проблема локализации «Русского Севера» специально не разрабатывалась, да и сам концепт стал применяться книговедами сравнительно недавно, в конце 1970-х годов. Ранее применялась либо этнографическая форма - «русский Север», либо формы, близкие по смыслу: «Север», «Север Европейской части России», «Российский Север», «Север России», «Северные губернии». Попробуем проанализировать практику применения этого понятия в книговедении, для того чтобы выявить основные тенденции в его трактовке, определить их истоки и, рассмотрев их, предложить вариант локализации.

Понятие «Русский Север» или его аналоги применяется археографами с XIX века. П.М. Строев, предлагая в 1823 г. проект масштабной археографической экспедиции по Европейской России, первый «Северный» этап планировал посвятить изучению книгохранилищ Новгородской, Санкт-Петербургской, Олонецкой, Архангельской, Вологодской, Вятской и частично Пермской губерний. Первоочередность работы в этом направлении он объяснял большим количеством старообрядцев в данном регионе, которые «...занесли с собою (в дальний Север) великое число всяких рукописей...» [4, с. 68]. Кроме того, эти территории меньше всего пострадали от «...нашествия врагов и сопряженному с тем опустошению и пожарам...» [4, с. 152]. На самом деле, за первый год работы экспедиции были обследованы хранилища на пространстве «от Онежской губы до верхней Пинеги, от Архангельска до Тотьмы, от Тотьмы до пределов зырянских...» [4, с. 196].

Спустя 40 лет археографические работы в северном направлении продолжил А.Е. Вик- 
торов. В 1890 г. были опубликованы «Описи рукописных собраний в книгохранилищах Сeверной России», к которым, судя по содержанию, были отнесены Архангельская, Вологодская, Тверская, Олонецкая, Нижегородская и Рязанская губернии. Надо заметить, что в архиве А.Е. Викторова рукописи под таким названием не нашлось. Зато обнаружился черновик, на обложке которого рукой Алексея Егоровича была сделана надпись: «Описи Северн. [«северн.» зачеркнуто] Монаст. б-къ» [5, л. 10]. География этой рукописи значительно шире, нежели представлено в издании. В ней собраны описания собраний печатных и рукописных книг, находившихся на территории Тверской, Нижегородской, Воронежской, Владимирской, Рязанской, Московской и других губерний. Из комментариев к «Описям» следует, что в течение 1876 г. А.Е. Викторовым были описаны «... библиотеки: Архангельской семинарии, Антониева-Сийского и Соловецкого монастырей, а также Холмогорского собора и Прилуцкого монастыря» [5, л. 3]. С сообщением об этих собраниях ученый выступил на заседании Археографической комиссии 20 июня 1877 года. Комиссия постановила напечатать их краткие описания в следующем томе. Но этого не произошло.

Описания, поступившие в Археографическую комиссию после смерти А.Е. Викторова вместе с другими его бумагами разбирались и готовились к изданию Д.П. Лебедевым, хранителем рукописей Московского Публичного и Румянцевского Музеев. Скорее всего, именно при публикации по непонятным причинам была нарушена хронология и география археографических поездок. Сложно также сказать, почему перечисленные территории были объединены под именем «Северная Россия», в предисловии к каталогу никаких комментариев по этому поводу нет.

В 1903 г. по поручению Отделения русского языка и словесности Российской Императорской академии наук В.И. Срезневским был предпринят ряд археографических экспедиций в Олонецкую, Архангельскую, Вологодскую и Пермскую губернии, в ходе которых была собрана коллекция рукописей, составивших «Северное собрание» (вошедшее позднее в состав Основного) Библиотеки Академии
Наук (БАН) [6]. Интересно, что в 1927 г., поступившие в НИОР БАН рукописи из упраздненных общественных организаций и учебных заведений Архангельска (Древлехранилище, Дом книги им. М.В. Ломоносова - ныне Архангельская областная научная библиотека им. Н.А. Добролюбова, Семинария, Миссионерская библиотека), и монастырей Архангельской губернии (Антониево-Сийского, НиколоКорельского, Соловецкого и Красногорского Богородицкого) были объединены в самостоятельное «Архангельское собрание», которое существует параллельно с «Северным».

Серия археографических экспедиций на Север, начатых В.И. Малышевым в 1930-е гг. и продолженная после Великой Отечественной войны, подразумевала обследование территорий по р. Печоре, с целью сбора «...устных преданий о протопопе Аввакуме» [7, с. 247]. В маршрут экспедиции были включены города Архангельск, Нарьян-Мар, Вологда, Киров, Великий Устюг, Сольвычегодск и села Яренск, Ижма, Усть-Цильма, Оксино, Усть-Вымь, которые относятся к современным Архангельской, Вологодской и Кировской областям, Республике Коми и Ненецкому автономному округу.

Открывшееся в Вологде в 1969 г. Северное отделение Археографической комиссии, возглавленное профессором П.А. Колесниковым, объявило приоритетным направлением своей деятельности «...сбор, публикацию и передачу на хранение в архивы... документов по истории Европейского Севера нашей страны...», территория которого была определена в границах «... Архангельской и Вологодской областей и Коми ACCP» $[8$, c. 1]. Но уже в обзоре рукописных памятников в музейных собраниях Европейского Севера в его состав оказалась включена Вятка (Кировская область).

В 1975 г. в монографии М.В. Кукушкиной, впервые в рамках книговедения, нам встретилось понятие «Русский Север» в топонимической форме. В монографии границы исследования не были оговорены автором, так как это было сделано ранее, в статье «Пути создания рукописных собраний в северных монастырях (Соловецком, Антониево-Сийском, НиколоКорельском, Александро-Свирском) в XVIXVII вв.» (1972), где главным принципом отбора материала стала его принадлежность 
к «...северу или крайнему северу западноевропейской части России, а также... к одной епархии - Архангельской (Соловецкий, Антониево-Сийский, Николо-Корельский) или смежной с ней - Олонецкой (АлександроСвирский)». Иными словами, под «Русским Севером» в данном случае следует понимать территории Архангельской и Олонецкой губерний [9]. Но уже в обзоре рукописных фондов БАН СССР (1988), к северным районам автором были добавлены Вологодская и Кировская области.

В 2000-х гг. популярность концепта стремительно выросла. Появился ряд предложений воспринимать понятие как культурологическую категорию, существующую на стыке географии и гуманитарных наук, в частности этнографии. В 2012 г. профессором факультета иностранных языков и регионоведения МГУ им. М.В. Ломоносова Владимиром Николаевичем Калуцковым была разработана теория геоконцептов как новых объектов географических исследований, где под геоконцептом подразумевается «любое значимое для определенного человеческого сообщества место, обладающее устойчивым образом». Фундаментальным свойством геоконцепта является его способность к «ретерриторизации» (к смене территориального прикрепления). В рамках этой теории автор выделил особый подвид геоконцептов, названных «экстерриториальными», т. е. не соотносящимися с конкретной территорией. К ним было предложено отнести «Русский Север» [1, с. 27-36].

Сложно сказать, насколько велико оказалось влияние культурологических теорий на книговедение, но общая тенденция была поддержана рядом исследователей. В 2008 г. вышел каталог «Лицевые апокалипсисы Русского Севера», в предисловии к которому авторы определяют состав «Русского Севера» территориями бассейнов рек Северная Двина, Мезень, Пинега, Печора, побережьями Онежского озера и Белого моря $[10$, с. 5]. Однако в самом каталоге география представленных рукописей значительно отличается. Из 11 только три содержат записи о бытовании на Севере Европейской части России. Остальные памятники были получены в дар или приобретены в букинистических магазинах г. Ленинграда, Горьковской области и даже в Рудном Алтае. Основания, по которым рукописи были определены как севернорусские, составители каталога не указали.

С 2014 г. вновь наблюдаются изменения в локализации Русского Севера книговедами. Основной зоной обследования археографическими экспедициями Института русской литературы (Пушкинского дома) - ИРЛИ РАН была названа Архангельская область (преимущественно Поморье) и северо-западная часть Кировской области. В данном случае включение Кировской области в состав Русского Сeвера было обусловлено наличием в ней поселений старообрядцев поморского согласия [11, c. 222].

Итак, на сегодняшний день книговедение вряд ли может продемонстрировать единство мнений о местоположении Русского Севера. Поэтому представление о территориальном составе этого «региона» книговедение предпочитает заимствовать из двух смежных наук, связанных между собой - этнографии и истории. Но дело в том, что в обеих вопрос локализации Русского Севера остается нерешенным по сей день.

Как объект исследования Русский Север привлекал внимание этнографов-любителей еще с конца XVIII века. Территория их интересов была ограничена, как правило, Apхангельской, Вологодской и Олонецкой губерниями. В XX в. с началом становления профессиональной этнографии ситуация изменилась. Уже к 1964 г. были проведены масштабные этнографические исследования, в результате которых русский этнос Европейской части России был разделен на три историко-культурные зоны: северную, южную и среднюю. К 1973 г. в этнографии сформировалось представление, о Русском Севере, как «территории, на которой распространен комплекс севернорусской традиционной бытовой культуры, по своей географической конфигурации весьма сходной с зоной севернорусских диалектов», т. е. «максимально объемно: русские местности Карелии и Коми края, Архангельская, Вологодская обл., а также прилегающие к ним районы С.-Петербурга, Новгородской, Тверской, Пермской и Вятской обл.» [12, с. 8].

Но уже в 1986 г. К.В. Чистов озвучил результаты независимых исследований, проведенных учеными-этнографами и этносоциологами: 
«...раницы расселения отдельных этносов (этнические территории), ареалы отдельных языков, отдельных комплексов или тем более элементов культуры... как правило, не совпадают» [13, с. 3]. В 1992 г. Т.А. Бернштам и К.В. Чистов, отмечали, «что ареальная или локальная дифференциация трех этнографических зон изучена... слабо и неравномерно» [13, с. 4]. Хуже всего поддавались разделению средняя и северная зоны. Поэтому более четкое зональное разграничение при «современном состоянии изучения Русского Севера <...> пока неосуществимо» $[14$, c. 10]. Положение усугублялось «почти непрерывной миграцией населения, исчезновением старых и формированием новых внутрирегиональных и локальных связей, многообразием этнических компонентов...» и т. д. В 1995 г. сотрудниками отдела этнографии восточнославянских народов Музея антропологии и этнографии им. Петра Великого (МАЭ РАН, создан в 1987 г.), было взято направление на изучение локальных групп, в первую очередь Двино-Важского бассейна «точнее ... по административному делению на 1991 г. территория ареала распределялась между районами Архангельской и Вологодской областей» $[13$, с. 5]. На сегодняшний день работа продолжается.

То же самое касается и исторической науки, к которой часто апеллируют этнографы, относя к Русскому Северу земли, которые «...c исторической точки зрения не могут быть отделены от севернорусского региона; северо-восточные районы быв. C-Петербургской губернии, а также бывшие Новгородская и Тверская губернии, северная часть Костромской губернии». Эта точка зрения во многом обусловлена стереотипом, который прочно проник в общественное сознание, о «монолитности Севера как заповедника древнерусской - “новгородской” культуры...» $[14$, с. 4] Почему-то считается, что Великому Новгороду принадлежит исключительная роль в освоении Русского Севера. На этом основании само понятие «Русский Север» транслируется на все территории, когда-либо и в какой-либо форме связанные с вечевой республикой. Как правило, это современные Архангельская, Вологодская, Мурманская, Пермская, Кировская, Новгородская, Псковская, Ленинградская области, Республика Карелия и Ненецкий автономный округ (НАО).
Данные стереотипы сформировались достаточно давно. Истоки их, надо полагать, скрываются в недрах антинорманнского направления отечественной историографии, инициатором которого был М.В. Ломоносов. В 1784 г. архангельский историк, член-корреспондент Академии наук В.В. Крестинин в своем труде, посвященном начальной истории Двинской земли, утверждал, что «владение Великоновгородских Славян над сею землею продолжалося более 600 лет, в языческие и Христианские веки» и закончилось в 1464 г., падением «вольного города», после которого Двинская земля вошла в состав централизованного государства $[15$, c. 2,10$]$. Той же версии придерживался и другой архангельский исследователь XVIII в. Козма Молчанов. При этом ни тот, ни другой не считали двинскую землю частью Новгородской республики и даже гипотетически не пытались уравнять права колонии и метрополии. Напротив, В.В. Крестинин учел все известные ему из источников попытки двинян выйти изпод власти Великого Новгорода, и охарактеризовал вхождение Двинской земли в состав централизованного государства как в высшей степени прогрессивное явление.

B XIX - начале XX в. в историографии произошло смещение акцентов в сторону идеализации «демократических» начал в политическом и административном устройстве вечевой республики. Эту точку зрения отстаивали историки, в большей или меньшей степени разделявшие идеи славянофильства, народничества и т. п. (И.Д. Беляев, С.Ф. Платонов, в некоторой степени М.М. Богословский, а впоследствии А.М. Гневушев, Н.Ф. Яницкий, М.Н. Покровский, В.Н. Бернадский и др.). Соответственно падение Великого Новгорода рассматривалось ими как катастрофа, в которой погибла не только вечевая республика, а вместе с ней все надежды на возможность демократического развития древнерусского государства в целом, но и, по выражению Н.И. Костомарова, «отдельная северная народность» [16, с. 235]. В советский период эта концепция была подавлена, но уже в 1990-е гг. вновь реанимирована, вероятно, на волне политических событий, в частности, в работе Р.Г. Скрынникова «Трагедия Новгорода».

Несмотря на притягательность и эмоциональность «новгородской парадигмы» с точ- 
ки зрения общественного сознания, с научной стороны она имеет ряд серьезных изъянов, наличие которых отмечали В.О. Ключевский, А.И. Никитский, М.К. Любавский, М.М. Богословский, С.Ф. Платонов, Н.И. Костомаров и многие другие. Первая и основная проблема - крайне слабая источниковая база по домосковскому периоду Русского Севера. По выражению С.Ф. Платонова, «...от этих древнейших времен не сохранилось почти никаких документов, ибо время и Москва их истребили» $[17$, с. 7]. Вторая проблема, является, на наш взгляд, прямым следствием первой. Отсутствие информации по административному, политическому и хозяйственному устройству северного региона в домосковский период было либо замещено сведениями из источников XVI-XVII вв., либо восстановлено на гипотетическом уровне, по аналогии с устройством самого Великого Новгорода. В качестве примера можно привести вывод С.Ф. Платонова о первоначальном заселении «русского Севера славянским племенем... из Великого Новгорода...» несмотря на то что «историческая наука не располагает точными данными о том, когда и как началось это заселение...» $[17$, с. 16].

Существует и еще одна проблема, причины которой не совсем понятны. Территории, определяемые историками как северные владения Новгородской республики, часто представляются зоной сплошного покрытия. Так, один из самых авторитетных исследователей севера Европейской России профессор М.М. Богословский писал: “"Поморскими городами”, Поморьем... назывались местности на севере Европейской части России по берегам Белого моря, по Онежскому озеру и рекам Онеге, Ceверной Двине, Мезени, Печоре и Каме с Вяткою. Весь этот обширный край принадлежал некогда Великому Новгороду» [18, с. 1].

Это представление, существующее по сей день, не совсем соответствует действительности. Историкам XIX в. - начала XX в. было хорошо известно о существовании в двинской земле наряду с новгородскими «боярщинами» так называемых «ростовщин». При этом максимальная концентрация новгородских владений в двинской земле приходилась на дельту Северной Двины. В XX в. археологи подтвердили и уточнили эти данные, зафиксировав в этих районах наличие поселений сезонного характера. То есть изначально новгородцев привлекали только «..промысловые районы Северного Поморья (южное побережье Белого моря, низовья Северной Двины и прибрежная кромка Канинской и Большеземельской тундр с выходом по этой полосе суши до низовьев р. Обь)» $[19$, c. 8]. Те районы Двино-Важского бассейна, которые платили в XII в. дань Новгороду, немногочисленны и четко фиксированы в Уставе князя Святослава Ольговича (1137). Активизация Новгородцев на северном направлении, согласно исследованиям В.Н. Бернадского, относится к XIV-XV векам. На это же время приходится обострение конфликта между Великим Новгородом, Ростовом и Москвой, сопровождающееся военными действиями, сведения о которых сохранились в летописях.

Безусловно, документальных свидетельств о Новгородском землевладении на Севере сохранилось больше всего, практически все они опубликованы («Грамоты Великого Новгорода и Пскова») и известны ученым. Сведений о Московском и Ростовском землевладении значительно меньше. Территории Москвы, в частности, зафиксированы в так называемых списках Двинских земель, некоторые пункты которых отмечены как объекты успешных притязаний Великого Новгорода. Во многих случаях неподвластность или формальная подвластность той или иной территории Великому Новгороду имеет лишь косвенные доказательства. Например, знаменитое Сийское Евангелие, написанное, согласно имеющейся в кодексе записи, в Москве в 1339-1340 гг., было дано вкладом в Богородицкий монастырь на Двине, фактически находившемся на территории, подчиненной Великому Новгороду. С.М. Кашатанов и Л.В. Столярова считают, что это - политическая акция, спланированная московским князем Иваном Даниловичем Калитой с целью заручиться поддержкой Двинской земли в условиях обострившихся отношений между Московским и Тверским княжествами [20]. Следует согласиться, что проводить эту акцию можно было только с одобрения «сюзерена» Двинской земли, т. е. Великого Новгорода, или предположить, что «сюзерен» таковым не являлся.

К сожалению, на сегодняшний день историческая наука не располагает данными о коли- 
честве и процентном соотношении Новгородского, Ростово-Суздальского и Московского землевладений на Севере. Но хочется заметить, что даже при минимальном соотношении «боярщин», «ростовщин» и московских владений в этом регионе, разговор об исключительной роли Новгорода в «освоении» Русского Севера теряет актуальность.

В связи с этим не менее интересным кажется вопрос о правомочности включения в состав Русского Севера территорий современных Кировской и Пермской областей, расположенных в бассейнах рек Камы и Вятки, не имеющих с точки зрения географии никакого отношения к Северу. Однако в истории территории этих двух областей часто ассоциируются с летописной Пермью Великой. А она, в свою очередь, у ряда исследователей (Ф.И. Страленберг, М.В. Ломоносов, Н.В. Татищев, К.С. Молчанов, Н.М. Карамзин и др.) отождествляется с легендарной Биармией скандинавских саг. «Имя нашей Перми есть одно с именем древней Биармии, которую составляли Архангельская, Вологодская, Вятская и Пермская Губернии», писал Н.M. Карамзин в начале XIX века. На сегодняшний день эту версию вряд ли можно считать обоснованной.

Еще в конце XIX в. исследователи отмечали, что в исторических источниках присутствует «неопределенность и сбивчивость в употреблении слова “Пермь”, то без всяких определений, то с прибавлением “Великая”, “Малая”, “Старая”» [21, с. 6]. Современные исследователи также забывают, что в истории России было две Перми - Пермь Вычегодская и Пермь Великая. По справедливому замечанию П.А. Корчагина, первая летописная Пермь - это Пермь Вычегодская, просвещать которую отправился в 1383 г. [21, с. 21] епископ Стефан Храп, будущий святитель Стефан Пермский. Ее местоположение достаточно подробно описано в Житии подвижника. Автор, Епифаний Премудрый, утверждает, что эту землю «обходят» четыре реки: Вымь, Вычегда, Вятка и Кама. Последняя - «убобходящия и проходящия всю Землю Пермьскую сквозь ню...». Тот же, кто хочет попасть в Пермь, должен «шествовать... от града Устюга рекою Вычегдою вверхъ дондеже внидет в самую Перм». Среди языческих народов, которые «...обседают живущи в суседех около ея...» [Перми] названа «...Пермь Великая глаголемая Чюсовая...» (л. 135) ${ }^{1}$ (р. Чусовая один из правых притоков Камы). C XVIXVII вв., по мнению П.А. Корчагина, топонимы стали постепенно «утрачивать реальную соотнесенность с конкретными российскими административно-территориальными образованиями...». Впоследствии, когда на Урале оформилось деление на уезды, Пермь Великую составили Чердынский, Соликамский и Кайгородский уезды, а Пермь Вычегодская оказалась разделена между Яренским и Усть-Сысольским уездом [21, с. 11].

С точки зрения современной экономики, статистики и географии, Кировская и Пермская области имеют лишь несколько точек соприкосновения с Севером Европейской части России. Согласно спискам Федеральной службы государственной статистики, опубликованным на официальном сайте организации, к районам Крайнего Севера в составе Коми-Пермяцкого округа Пермского края отнесены только три административные единицы: Гайнский, Косинский и Кочёвский районы. Кировская область в эти списки не включена. Безусловно, через эти территории издавна пролегают торговые пути. Но в настоящий момент сложно сказать, насколько правомочно включение транзитных земель в территориальное ядро Русского Севера.

Присоединение Кировской и Пермской областей в состав Русского Севера как районов концентрации старообрядческих общин поморского толка (что часто наблюдается в книговедческой литературе), также не имеет, на наш взгляд, достаточных доводов. Отношение этих общин к территориям вокруг реки Выг номинально. По сути, их объединяет только идея, а ее трактовка и отражение в объектах материальной культуры несет в себе мощный пласт местных традиций и культурных особенностей. Кроме того, Кама и Вятка - далеко не единственные места поселений старообрядцев-помор-

1 Житие Стефана архиепископа Пермского // Сборник Житий. Перв. пол. XVII в. 269 л. Отдел рукописей Российской государственной библиотеки (ОР РГБ). Ф. 247 (Рог.). № 593. Л. 125-265. Мы приводим цитаты по одному из поздних списков «Жития...», имеющему некоторые расхождения с текстом, опубликованным Г.М. Прохоровым по списку Государственного исторического музея. Синодальное собрание. № 993. 
цев. Их общины есть в Поволжье, Прибалтике и далеко за рубежами России.

То же касается и территорий Ленинградской, Новгородской и Псковской областей. С точки зрения географии эти объекты относятся к северо-западу России. В историческом аспекте города Псков и Великий Новгород, крупные экономические и культурные центры, находившиеся в центре политических событий, при постоянном контакте с Западной Европой, так как оба являлись участниками Ганзейского союза, обладали статусом вечевых республик. Говорить об их духовных и культурных связях с отдаленными северными колониями Великого Новгорода, находившимися от него преимущественно в даннической зависимости, и одновременно являвшимися сырьевой базой и яблоком раздора для трех крупных государственных образований, вряд ли возможно.

Учитывая все эти исторические нюансы, возникает вопрос о дальнейшей необходимости настаивать на «монолитности» Русского Севера в территориальном и культурном отношении с Великим Новгородом, Ростовом или Москвой до 1478 года? По сути, объединяющим фактором для разрозненных в политическом отношении северных земель стало их включение в состав централизованного государства. Благодаря этому событию постепенно определился их территориальный, административный и экономический статус. С этого времени начался многовековой процесс оформления севернорусского типа культуры. Удаленное географическое положение, природные условия, род хозяйственной деятельности жителей, малонаселенность огромной территории, особое социальное положение (значительный процент черносошного, а в дальнейшем государственного крестьянства) и множество иных факторов не могли не отразиться на образе мыслей и объектах материальной культуры, что так «восхищало» профессиональных исследователей и любителей старины в XIX-XX веках. Вполне вероятно, что «наследник» великоновгородских вольностей и традиций, именуемый сегодня «Русский Север» и не имеющий территории, существует только в общественном воображении. В конце концов, если внимательно ознакомиться с историей происхождения само- го понятия, может оказаться что для его «переосмысления» не так уж много оснований.

Считается, что автором топонима Русский Север является архангельский губернатор Александр Платонович Энгельгардт, опубликовавший в 1897 г. путевые заметки о своей рабочей поездке по Архангельской губернии. «РУССКИЙ СЕВЕР: путевые записки» - заголовок на обложке издания, а текст самой книги начинается словами: «При первом, даже поверхностном, знакомстве с местными условиями и нуждами русского Севера, составляющего Архангельскую губернию...» [22, с. 1]. Ни в тексте, ни в заголовке нет ни малейшего намека на топонимическую форму. То же самое касается и издания труда М.М. Богословского «Земское самоуправление на русском Севере», границы которого М.M. Богословский определял в соответствии с «Новгородской парадигмой». Как уже было сказано выше, именно эта точка зрения приобрела большее количество сторонников. Топонимическая форма Русский Север появилась чуть позже, в 1909 г. на обложке и в тексте первого выпуска журнала «Известия Архангельского Общества изучения Русского Севера». Но при этом следует отметить, что в журнале, который выходил с 1909 по 1919 г., помимо статей, посвященных северу Европейской части России, публиковалось значительное количество материалов о Сибири как территории, связанной с Архангельском торговыми отношениями и близкими природными и географическими условиями. И в этом случае под Русским Севером следовало понимать весь Север Европейской части России и Север Сибири. В таком контексте употребление топонимической формы выглядело вполне оправданным, так как речь шла о территориях, освоенных русским этносом и включенных в состав Российской империи, которые сейчас все чаще именуются «Российским севером». В любом случае, под понятиями «Русский Север», «Российский Север», «Север Европейской части России» подразумеваются конкретные территории, обладающие границами, определенными в процессе физико-географического, а затем экономического районирования.

Безусловно, в современных реалиях невозможно проводить исследования, игнорируя опыт смежных отраслей науки. Но и увлече- 
ние абстракциями с пренебрежением мелкими, казалось бы несущественными деталями может привести к ошибочным выводам и к заведомому искажению исторической картины, что, собственно, и происходит с «Русским Севером». Воспринимая его как нечто в крайней степени сакральное и символичное, мы забываем, что по справедливому замечанию Ю.В. Линника, «Русский Север - совсем не утопия: это место, которое есть...» [23].

\section{Список источников}

1. Калуцков В.Н. Основы этнокультурного ландшафтоведения : учебное пособие. Москва : Изд-во Московского ун-та, 2000. 94 с.

2. Жеребцов И.Л., Журавлев П.С., Шабаев Ю.П. «Русский Север»: культурные границы и культурные смыслы // Труды Института языка, литературы и истории Коми научного центра УрОРАН. Вып. 71. Сыктывкар : Изд-во Коми науч. центр УрО РАН, 2012. С. 6-28.

3. Соловъева А.Н. «Русский Север»: смысловые горизонты этничности в культурном пространстве // Геокультурное пространство Европейского Севера: генезис, структура, семантика : сб. науч. статей. Поморские чтения по семиотике культуры. Вып. 5. Архангельск, 2011. C. $212-221$.

4. Барсуков Н.П. Жизнь и труды П.М. Строева. Санкт-Петербург : Тип. В.С. Балашева, 1878. $668 \mathrm{c}$.

5. Викторов А.Е. Описи монастырских библиотек // Отдел рукописей Российской государственной библиотеки (ОР РГБ). Ф. 51. К. 5. Ед. хр. 34.

6. Дмитриев Л.А., Копанев А.И. Археографическая экспедиция в Беломорский, Кемский и Лоухский районы Карельской АССР летом 1959 г. // Труды Отдела древнерусской литературы (ТОДРЛ). T. XVII. Москва; Ленинград : Изд-во АН СССР, 1961. С. 531-544.

7. Малышев В.И. Сведения о собраниях рукописей и старопечатных книг в некоторых городах северных областей // Труды Отдела древнерусской литературы (ТОДРЛ). T. IV. Москва ; Ленинград : Изд-во АН СССР, 1940. С. 247-253.

8. Материалы по истории Европейского Севера СССР: Сев. Археогр. сб. Вып. 1. Труды вологодской научной конференции по историографии и источниковедению. Декабрь 1969. Вологда : [б. и.], 1970. 539 с.
9. Кукушкина М.В. Пути создания рукописных собраний в северных монастырях (Соловецком, Антониево-Сийском, Николо-Корельском, Александро-Свирском) в XVI в. // Вспомогательные исторические дисциплины. Ленинград : Наука, 1972. Вып. 4. С. 105-120.

10. Лицевые апокалипсисы Русского Севера : рукописи XVII-XIX вв. из фондов Древлехранилища Пушкинского дома. Санкт-Петербург : Издво Пушкинского Дома, 2008. 175 с.

11. Бильдюг А.Б., Бобров А.Г., Васкул А.И., Комелина Н.Г. Обзор фольклорных и археографических экспедиций Пушкинского Дома 2008-2013 годов // Вестник Российского гуманитарного научного фонда. 2014. № 3. С. 215-224.

12. Бернштам T.А. Роль верхневолжской колонизации в освоении Русского Севера (IX-XV вв.) // Фольклор и этнография Русского Севера. Ленинград : Наука, 1973. С. 5-29.

13. Русский Север: Ареалы и культурные традиции. Санкт-Петербург : Наука, 1992. 270 с.

14. Русский Север: к проблеме локальных групп. Санкт-Петербург : Наука, 1995. 320 с.

15. Крестинин В.В. Исторические начатки о двинском народе древних, средних, новых и новейших времен. Санкт-Петербург : Императорская академия наук, 1784.69 с.

16. Костомаров Н.И. Севернорусские народоправства. Времена удельно-вечевого уклада. СанктПетербург : Изд. Д.Е. Кожанчикова, 1863. Т. 2. $456 \mathrm{c}$.

17. Платонов С.Ф. Прошлое Русского Севера : очерки по истории колонизации Поморья. Берлин : Обелиск, 1924. 107 с.

18. Богословский М.М. Земское самоуправление на Русском Севере в XVII в. Москва : Синодальная типография, 1909. T. 1. VIII, 322, 105 с.

19. Овсянников О.В. Средневековые города Архангельского Севера : Люди. События. Даты. Архангельск : Сев.-Зап. кн. изд-во, 1992. 349 с.

20. Каштанов С.М., Столярова Л.В. Еще раз о дате так называемого Сийского евангелия // Сообщения Ростовского музея. Ростов, 1995. Вып. 8. C. 3-48.

21. Корчагин П.А. Пермь. «Что в имени...» // Вестник Пермского научного центра. 2013. №. 4. C. 4-21.

22. Энгельгардт А.П. Русский север : путевые записки. Санкт-Петербург : Изд. А.С. Суворина, 1897. $258 \mathrm{c}$. 
23. Линник Ю.В. Русский Север как духовная ценность : [рецензия на кн.: Пермиловская А.Б. Русский Север как особая территория наследия. Архангельск : Правда Севера ; Екатеринбург : УрО
PAH, 2010. 552 с.] // Открытый текст : электронное периодическое издание. URL: http:// www.opentextnn.ru/space/books/?id=4281 (дата обращения: 17.07.2018).

\section{Terra Incognita of Russian Bibliology: On Application and Localization of the Concept of "Russian North"}

\section{Elena S. Trifilova}

Russian State Library, 3/5, Vozdvizhenka Str., Moscow, 119019, Russia

E-mail: estrifilova@gmail.com

\begin{abstract}
The concept of "Russian North" is actively used in the media and in scientific literature. However, only few people think about its meaning. In the field of bibliology, the uncertainty of the idea of the Russian North territory complicates the selection of material for studying the book culture of this region. Analysis of the practice of using the concept shows that this problem appeared in the 19th century, when researchers differently defined the territory of the Russian North. In most cases, they were directed by the conclusions of historical science, which included in this region all the lands ever and in any way connected with the Novgorod Republic. This stereotype, formed almost 200 years ago, still exists now. However, the data obtained as a result of archeological and historical research carried out over the last 50 years cast doubts on the validity of the Novgorod paradigm.

In ethnography, methods of which began to be actively used in book studies in the second half of the 20th century, there is also no unified opinion on the territorial structure of the Russian North. Attempts to combine its borders with the areas of distribution of North Russian dialects and the complex of traditional North Russian household culture have shown ineffectiveness of this method in modern world.

On the one hand, new culturological theories that appeared at the cusp of the 20th-21st centuries offered new aspects for studying the Russian North, but on the other hand, they moved it into the field of abstraction, actually depriving it of its geographic boundaries. As long as the issue of the Russian North locali-
\end{abstract}

zation remains open in bibliology, this study attempts to systemize and analyze the accumulated information. As a result, the article raises questions about the necessity of further preservation of the stereotype; about the eligibility to classify to the Russian North the territories that are not related to it in terms of geography, or have a conditional relation from the point of view of history; about the rightness of application of the toponymic form of the concept in relation to the North European part of Russia, without regard to the North of Siberia. In conclusion, the article makes some correction in relation to the authorship of the term "Russian North", which is traditionally attributed to the Civil Governor of Arkhangelsk A.P. Engelgardt.

Key words: Russian North, bibliology, archeography, ethnography, North of the European part of Russia, A.P. Engelgardt.

Citation: Trifilova E.S. Terra Incognita of Russian Bibliology: On Application and Localization of the Concept of "Russian North", Observatory of Culture, 2018, vol. 15, no. 6, pp. 729-739. DOI: 10.25281/2072-3156-2018-15-6-729-739.

\section{References}

1. Kalutskov V.N. Osnovy etnokul'turnogo landshaftovedeniya: uchebnoe posobie [Foundations of Ethnocultural Landscape Studies: tutorial]. Moscow, Moskovskogo Universiteta Publ., 2000, 94 p.

2. Zherebtsov I.L., Zhuravlev P.S., Shabaev Yu.P. "Russian North": Cultural Boundaries and Cultural Meanings, Trudy Instituta yazyka, literatury $i$ istorii Komi nauchnogo tsentra UrORAN [Proceedings of the Institute of Language, Literature and History of the Komi Scientific Center of the Ural Branch of the Russian Academy of Sciences], issue 71. Syktyvkar, Komi Nauchnyi Tsentr UrO RAN Publ., 2012, pp. 6-28 (in Russ.).

3. Solovyova A.N. "Russian North": Semantic Horizons of Ethnicity in the Cultural Space, Geokul'turnoe prostranstvo Evropeiskogo Severa: genezis, struktura, semantika: sb. nauch. statei. Po- 
morskie chteniya po semiotike kul'tury [Geocultural Space of European North: Genesis, Structure, Semantics: collected scientific articles. Pomor Readings on Semiotics of Culture], issue 5. Arkhangelsk, 2011, pp. 212-221 (in Russ.).

4. Barsukov N.P. Zhizn' i trudy P.M. Stroeva [P.M. Stroev's Life and Works]. St. Petersburg, V.S. Balasheva Publ., 1878, 668 p.

5. Viktorov A.E. Inventories of Monastic Libraries, Otdel rukopisei Rossiiskoi gosudarstvennoi biblioteki (OR RGB) [Manuscripts Department of the Russian State Library], coll. 51, aids 5, item 34 (in Russ.).

6. Dmitriev L.A., Kopanev A.I. Archaeographic Expedition in the Belomorsky, Kemsky and Loukhsky Districts of the Karelian ASSR in the Summer of 1959, Trudy Otdela drevnerusskoi literatury (TODRL) [Proceedings of the Department of Old Russian Literature], vol. XVII. Moscow, Leningrad, AN SSSR Publ., 1961, pp. 531-544 (in Russ.).

7. Malyshev V.I. Information on Collections of Manuscripts and Early Printed Books in Some Cities of the Northern Regions, Trudy Otdela drevnerusskoi literatury (TODRL) [Proceedings of the Department of Old Russian Literature], vol. IV. Moscow, Leningrad, AN SSSR Publ., 1940, pp. 247-253 (in Russ.).

8. Materials on the History of the USSR European North: Northern Archaeographical Collection. Issue 1. Proceedings of the Vologda Scientific Conference on Historiography and Source Studies. December 1969. Vologda, 1970, 539 p. (in Russ.).

9. Kukushkina M.V. The Ways of Creation of Manuscript Collections in Northern Monasteries (Solovetsky, Antonievo-Siisky, Nikolo-Korelsky, Aleksandro-Svirsky) in the 16th Century, Vspomogatel'nye istoricheskie distsipliny [Auxiliary Historical Disciplines]. Leningrad, Nauka Publ., 1972, issue 4, pp. 105-120 (in Russ.).

10. Illuminated Apocalypses of the Russian North: Manuscripts of the 17th-19th Centuries from the Archive of the Pushkin House. St. Petersburg, Pushkinskogo Doma Publ., 2008, 175 p. (in Russ.).

11. Bildyug A.B., Bobrov A.G., Vaskul A.I., Komelina N.G. Overview of the Folklore and Archeographic Expeditions of the Pushkin House in 2008-2013, Vestnik Rossiiskogo gumanitarnogo nauchnogo fonda [Bulletin of the Russian Foundation for Humanities], 2014, no. 3, pp. 215-224 (in Russ.).

12. Bernshtam T.A. The Role of the Upper Volga Colonization in the Russian North Development (9th- 15th Centuries), Fol'klor i etnografiya Russkogo Severa [Folklore and Ethnography of the Russian North]. Leningrad, Nauka Publ., 1973, pp. 5-29 (in Russ.).

13. Russian North: Habitats and Cultural Traditions. St. Petersburg, Nauka Publ., 1992, 270 p. (in Russ.).

14. Russian North: On the Problem of Local Groups. St. Petersburg, Nauka Publ., 1995, 320 p. (in Russ.).

15. Krestinin V.V. Istoricheskie nachatki o dvinskom narode drevnikh, srednikh, novykh i noveishikh vremen [Historical Beginnings of the Dvina People of Ancient, Middle, New and Modern Times]. St. Petersburg, Imperatorskaya Akademiya Nauk Publ., 1784, 69 p.

16. Kostomarov N.I. Severnorusskie narodopravstva. Vremena udel'no-vechevogo uklada [North Russian Popular Sovereignties. The Period of Domain-Veche System]. St. Petersburg, D.E. Kozhanchikova Publ., 1863, vol. 2, 456 p.

17. Platonov S.F. Proshloe Russkogo Severa: ocherki po istorii kolonizatsii Pomor'ya [The Past of the Russian North: Essays on the History of Pomorye Colonization]. Berlin, Obelisk Publ., 1924, 107 p.

18. Bogoslovsky M.M. Zemskoe samoupravlenie na Russkom Severe v XVII v. [Zemstvo Self-Government in the Russian North in the 17th Century]. Moscow, Sinodal'naya Publ., 1909, vol. 1, VIII, 322, 105 p.

19. Ovsyannikov O.V. Srednevekovye goroda Arkhangel'skogo Severa: Lyudi. Sobytiya. Daty [Medieval Cities of the Arkhangelsk North: People. Events. Dates]. Arkhangelsk, Severo-Zapadnoe Publ., 1992, 349 p.

20. Kashtanov S.M., Stolyarova L.V. Once Again on the Date of the So-Called Siiskoe Gospel, Soobshcheniya Rostovskogo muzeya [Messages of the Rostov Museum]. Rostov, 1995, issue 8, pp. 3-48 (in Russ.).

21. Korchagin P.A. Perm. "What does the Name Mean...”, Vestnik Permskogo nauchnogo tsentra [Bulletin of the Perm Scientific Center], 2013, no. 4, pp. 4-21 (in Russ.).

22. Engelgardt A.P. Russkii sever: putevye zapiski [Russian North: Travel Notes]. St. Petersburg, A.S. Suvorina Publ., 1897, $258 \mathrm{p}$.

23. Linnik Yu.V. Russian North as a Spiritual Value, Otkrytyi tekst: elektronnoe periodicheskoe izdanie [Open Text: Electronic Periodical Publication]. Available at: http://www.opentextnn.ru/space/ books/?id=4281 (accessed 17.07.2018) (in Russ.). 